\title{
Importance of environmental geotechnics
}

1 Paul M. Johnston BASC, MSc, FGS, MICE Associate Professor, Department of Civil, Structural and Environmental Engineering, Trinity College Dublin, Dublin, Ireland
2 Brendan C. O’Kelly PhD, FTCD, CEng CEnv MICE

Associate Professor, Department of Civil, Structural and Environmental Engineering, Trinity College Dublin, Dublin, Ireland
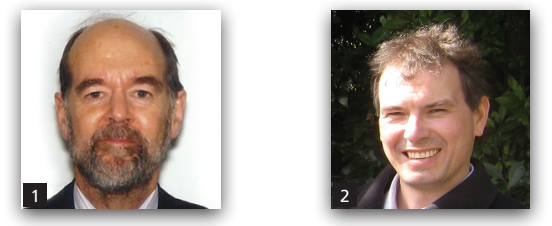

Environmental Geotechnics might, at first sight, seem to be a tautology in that soils and rocks are inherent parts of the natural environment. However, this evolving discipline within the umbrella of civil engineering has grown out of the realisation that the principles of geotechnical engineering can be applied very effectively in the solution of many environmental problems that have become increasingly acute with the burgeoning density of human habitation. The focus of Environmental Geotechnics, initially, as reflected in an ASCE Conference of 2000 (Zimmie, 2000), was on various forms of waste and how they behave geotechnically. What are the criteria for the structural stability of landfilled municipal solid waste, for example, especially when the material is undergoing chemical and biological degradation over many years? Sewage sludges, industrially contaminated soils and stabilised waste all have their own geotechnical characteristics when considering disposal and management (Bareither et al., 2012; O'Kelly, 2004). Clearly, where the natural environment is concerned, hydrology is frequently the driver of contaminant movement as well as structural instability problems. Hence, there is a strong overlap with hydrological considerations, particularly with respect to unsaturated conditions in both natural and manufactured materials (Kelln et al., 2007), but the geotechnical approach to analysis has much to offer in such assessments. The interaction between hydrological and geotechnical analyses has been a growing part of environmental geotechnics.

More recently, the breadth of hydro-environmental problems amenable to geotechnical analysis has widened, for example, in the field of wetland conservation (McInerney et al., 2006) - what mitigation measures can be applied to the margins of peatlands in order to prevent dessication and promote the growth of species contributing to biodiversity? The improvement, reinforcement and stabilisation of soils are related areas undergoing rapid development in techniques and methods (Phear and Harris, 2008). Some work by the authors include, for instance, investigation of geogrid reinforcement incorporating in-plane drainage capability that can facilitate the use of marginal fill in the construction of reinforcedearth structures (O'Kelly and Naughton, 2008), improvement of the geomechanical properties of sand using biopolymers (Khatami and O'Kelly, 2013) and stimulated decomposition in peat for engineering applications (Pichan and O'Kelly, 2013). The discipline of environmental geotechnics has made significant contributions to technical and design skills in the field of soil and groundwater remediation (Bhandari et al., 2007), installation and performance of containment systems for control of contaminant migration (Rowe, 2014) and geothermal science (Banks, 2012). The influence of climate change on many of these environmental issues presents significant challenges to both hydrological and geotechnical analyses to which Environmental Geotechnics as a discipline has much to contribute.

It could be argued that many of these areas are not exclusive enough to define a new discipline of environmental geotechnics, distinct from traditional geotechnical engineering. Indeed, in the early years of geotechnical engineering, the problems were considered in terms of classical soil mechanics and soil science. Typically, the work concentrated on hydro-mechanical interactions, such as consolidation and chemical-mechanical interactions involving clay mineralogy and pore fluid geochemistry (Soga and Jefferis, 2008). Many of these treatments could be considered steady state or aimed at determining long-term equilibrium conditions. The detail of the time dependency of the chemical, biological or biogeochemical processes was considered too complex to analyse, or they were simply treated as 'lumped' processes. As geotechnical engineering has begun to tackle more environmentally related problems, and, indeed, to use biological or chemical processes in the engineering of soil properties (Mitchell and Santamarina, 2005; O'Kelly and Pichan, 2014; Tastan et al., 2011), much deeper consideration has been given to the nature of the processes involved and their time dependency. Other examples are to be found in understanding the nature of biological clogging (McIsaac and Rowe, 2007; Nikolova-Kuscu et al., 2013) or the bio-chemical improvement and (or) stabilisation of soils and the optimisation of such processes. Descriptions of the potential of soil improvement by biocalcification, for instance, are provided by DeJong et al. (2013) and Martinez et al. (2013). While geotechnical engineering by its nature has crossed a number of disciplines, the greater involvement of broader environmental aspects has increased the multidisciplinary nature of the subject to the extent that Environmental Geotechnics is considered a distinctive subject area. 
Another dimension to engineering research in recent years, perhaps in the face of climate change and increasing economic pressures, is the need to define 'sustainability' in any design (Griffin and O'Kelly, 2014; Holt et al., 2010). Given its interdisciplinary character, the concept of sustainability is no less a fundamental part of the growth in environmental geotechnics, for example, including areas of material reuse, recycling and reengineering, foundation rehabilitation and reuse (Butcher et al., 2006). Conventionally, sustainability incorporates the three pillars of economics, sociology and environment/technology, and already papers are emerging specific to geotechnical engineering. For example, Jefferson et al. (2007) have suggested 107 environmental geotechnical indicators to be used to define sustainability for geotechnical projects. Clearly, the concept of sustainability is embracing much broader issues than involved in previous approaches of determining 'design life' for a project. The interdisciplinary nature of sustainability, as now widely recognised, means that the concept is very much the remit of environmental geotechnics. Although geotechnical design has always been understood to incorporate the need for a 'balance with nature', just what this means in terms of current definitions of 'sustainability' will require much more thought and research.

Thus, the process-dependent nature of interaction with 'the environment' is fertile ground for the growing research in environmental geotechnics, which is already resulting in a better understanding of soil biogeochemistry and its management (Manassero et al., 2013). The inherent interdisciplinary aspects of environmental issues have given rise to evolving ideas as to the meaning of sustainability in geotechnical engineering. The Proceedings of the ICE, Environmental Geotechnics is a welcome and much needed focus and forum for the publication and discussion of the growing research in these areas.

\section{REFERENCES}

Bareither CA, Benson CH and Edil TB (2012) Effects of waste composition and decomposition on the shear strength of municipal solid waste. Geotechnical and Geoenvironmental Engineering 138(10): 1161-1174.

Banks D (2012) An Introduction to Thermogeology: Ground Source Heating and Cooling, 2nd edn. Wiley-Blackwell Chichester, Sussex, UK, 544 pp.

Bhandari A, Surampalli RY, Champagne P et al. (eds) (2007) Remediation Technologies for Soils and Groundwater. American Society of Civil Engineers, Reston, VA, USA, $458 \mathrm{pp}$.

Butcher AP, Powell JJM and Skinner HD (eds) (2006) Reuse of Foundations for Urban Sites: A Best Practice Handbook. BRE Press, Bracknell, Berkshire, UK, 144 pp.

DeJong JT, Soga K, Kavazanjian E et al. (2013) Biogeochemical processes and geotechnical applications: progress, opportunities and challenges. Géotechnique 63(4): 287-301.

Griffin H and O'Kelly BC (2014) Sustainability of combined vacuum and surcharge preloading. In Proceedings of the 2014 Geo-Congress: Geo-Characterization and Modeling for Sustainability, Atlanta, Georgia, USA (Abu-Farsakh M, Yu X and Hoyos LR (eds)). American Society of Civil Engineers, Reston, VA, USA, GSP 234, pp. 3826-3835.

Holt DGA, Jefferson I, Braithwaite PA and Chapman DN (2010) Sustainable geotechnical design. In Proceedings of GeoFlorida 2010: Advances in Analysis, Modeling and Design, Orlando, Florida, USA (Fratta DO, Puppala AJ and Muhunthan B (eds)). American Society of Civil Engineers, Reston, VA, USA, GSP 199, pp. 2925-2932.

Jefferson I, Hunt DVL, Birchall CA and Rogers CDF (2007) Sustainability indicators for environmental geotechnics. Proceedings of the ICE, Engineering Sustainability 160(2): 57-78.

Kelln C, Barbour L and Qualizza C (2007) Preferential flow in a reclamation cover: hydrological and geochemical response. Geotechnical and Geoenvironmental Engineering 133(10): 1277-1289.

Khatami HR and O'Kelly BC (2013) Improving mechanical properties of sand using biopolymers. Geotechnical and Geoenvironmental Engineering 139(8): 1402-1406.

Manassero M, Dominijanni A, Foti S and Musso G (eds) (2013) Coupled Phenomena in Environmental Geotechnics. CRC Press/Balkema, The Netherlands, 732 pp.

Martinez BC, DeJong JT, Ginn TR et al. (2013) Experimental optimization of microbial-induced carbonate precipitation for soil improvement. Geotechnical and Geoenvironmental Engineering 139(4): 587-598.

McInerney GP, O'Kelly BC and Johnston PM (2006) Geotechnical aspects of peat dams on bog land. In Proceedings of the 5th International Congress on Environmental Geotechnics, Cardiff, UK (Thomas HR (ed)). Thomas Telford, London, Vol. 2, pp. 934-941.

Mclsaac R and Rowe RK (2007) Clogging of gravel drainage layers permeated with landfill leachate. Geotechnical and Geoenvironmental Engineering 133(8): 1026-1039.

Mitchell JK and Santamarina JC (2005) Biological considerations in geotechnical engineering. Geotechnical and Geoenvironmental Engineering 131(10): 1222-1233.

Nikolova-Kuscu R, Powrie W and Smallman DJ (2013) Mechanisms of clogging in granular drainage systems permeated with low organic strength leachate. Canadian Geotechnical Journal 50(6): 632-649.

O'Kelly BC (2004) Geotechnical aspects of sewage sludge monofills. Proceedings of the ICE, Municipal Engineer 157(3): 193-197.

O'Kelly BC and Naughton PJ (2008) On the interface shear resistance of a novel geogrid with in-plane drainage capability. Geotextiles and Geomembranes 26(4): 357-362.

O'Kelly BC and Pichan SP (2014) Effect of decomposition on physical properties of fibrous peat. Proceedings of the ICE, Environmental Geotechnics 1(1): 22-32.

Phear AG and Harris SJ (2008) Contributions to Géotechnique 19482008: Ground improvement. Géotechnique 58(5): 399-404.

Pichan SP and O'Kelly BC (2013) Stimulated decomposition in peat for engineering applications. Proceedings of the ICE, Ground Improvement 166(3): 168-176. 
Rowe RK (2014) Performance of GCLS in liners for landfill and mining applications. Proceedings of the ICE, Environmental Geotechnics 1(1): 3-21.

Soga K and Jefferis SA (2008) Contributions to Géotechnique 1948-2008: Soil science and interdisciplinary aspects of geotechnical engineering. Géotechnique 58(5): 441-448.

Tastan EO, Edil TB, Benson CH and Aydilek AH (2011) Stabilization of organic soils with fly ash. Geotechnical and Geoenvironmental Engineering 137(9): 819-833.
Zimmie TF (ed) (2000) In Environmental Geotechnics: Proceedings of Sessions of Geo-Denver 2000, Denver, Colorado, USA. American Society of Civil Engineers, Reston, VA, USA, GSP 105, 176 pp.

\section{WHAT DO YOU THINK?}

To discuss this paper, please submit up to 500 words to the editor at journals@ice.org.uk. Your contribution will be forwarded to the author(s) for a reply and, if considered appropriate by the editorial panel, will be published as a discussion in a future issue of the journal. 